\title{
Correction to: Chimeric Antigen Receptor T Cell-Related Neurotoxicity: Mechanisms, Clinical Presentation, and Approach to Treatment
}

Jessica Rice, $M D^{1}$

Sarah Nagle, $M D^{2}$

Julie Randall, $B A^{3}$

Holly E. Hinson, MD MCR ${ }^{1, *}$

\author{
Address \\ ${ }^{*}, 1$ Department of Neurology, Oregon Health \& Science University, 3181 SW Sam \\ Jackson Park Road, CR-127, Portland, OR, 97239, USA \\ Email: hinson@ohsu.edu \\ ${ }^{2}$ Department of Medicine, Oregon Health \& Science University, Portland, OR, USA \\ ${ }^{3}$ Portland State University, Portland, OR, USA
}

Published online: 9 August 2019

(C) Springer Science+Business Media, LLC, part of Springer Nature 2019

The online version of the original article can be found at https://doi.org/10.1007/s11940-019-0580-3

Correction to: Curr Treat Options Neurol (2019) 21: 40

https://doi.org/10.1007/s11940-019-0580-3

The correct spelling of the co-author should be listed as Sarah Nagle, MD.

The original article has been corrected.

\section{Publisher's Note}

Springer Nature remains neutral with regard to jurisdictional claims in published maps and institutional affiliations. 